\title{
GAMBARAN PENGETAHUAN, SIKAP MAHASISWA TENTANG PERILAKU SEKS BEBAS DI STIKES RESPATI TASIKMALAYA TAHUN 2015
}

\author{
OLEH : \\ DADAN YOGASWARA,S.KM,M.KM
}

\section{A. ABSTRAK}

Berdasarkan hasil Survei Demografi Kesehatan Indonesia 2012 komponen Kesehatan Reproduksi Remaja (SDKI 2012 KRR), bahwa secara nasional terjadi peningkatan angka remaja yang pernah melakukan hubungan seksual pranikah dibandingkan dengan data hasil Survei Kesehatan Reproduksi Remaja Indonesia (SKRRI) 2007. Hasil survei SDKI 2012 KRR menunjukkan bahwa sekitar 9,3\% atau sekitar 3,7 juta remaja menyatakan pernah melakukan hubungan seksual pranikah, sedangkan hasil SKRRI 2007 hanya sekitar 7\% atau sekitar 3 juta remaja. Sehingga selama periode tahun 2007 sampai 2012 terjadi peningkatan kasus remaja yang pernah melakukan hubungan seksual pranikah sebanyak 2,3\%.Tujuan penelitian adalah mengetahui gambaran pengetahuan dan sikap mahasiswa tentang perilaku seks bebas di STIKes Respati Tasikmalaya tahun 2015.

Jenis penelitian yang digunakan adalah penelitian kuantitatif dengan metode deskriptif.Populasi dalam penelitian ini adalah seluruh mahasiswa STIKes Respati Tasikmalaya peserta pelatihan kesehatan reproduksi yaitu 72 orang. Tehnik pengambilan sampel dalam penelitian ini adalah total sampling dimana seluruh populasi dijadikan sampel dalam penelitian.Instrumen dalam penelitian ini menggunakan kuesioner 20 pertanyaan untuk pengetahuan dan 10 pernyataan sikap. Analisis data dalam penelitian ini adalah analisis univariat.

Hasil penelitian didapatkan bahwa mayoritas pengetahuan mahasiswa tentang seks bebas adalah kurang yaitu 30 orang $(41,7 \%)$ serta mayoritas sikap mahasiswa tentang perilaku seks bebas adalah tidak mendukung yaitu 87,5\%.

Diharapkan mahasiswa dapat meningkatkan pencarian informasi tentang resiko perilaku seks bebas pada remaja melalui penyuluhan dan konseling.

\section{Kata kunci : Pengetahuan, sikap perilaku seks bebas}




\section{B. PENDAHULUAN}

Perilaku seksual menurut Sarwono (2007) merupakan segala bentuk perilaku yang didorong oleh hasrat seksual, baik dengan lawan jenis maupun dengan sesama jenis. Bentuk perilaku seksual, mulai dari bergandengan tangan (memegang lengan pasangan), berpelukan (seperti merengkuh bahu, merengkuh pinggang), bercumbu (seperti cium pipi, cium kening, cium bibir), meraba bagian tubuh yang sensitif, menggesek-gesekkan alat kelamin sampai dengan memasukkan alat kelamin. Demikian halnya dengan perilaku seksual pranikah pada remaja akan muncul ketika remaja mampu mengkondisikan situasi untuk merealisasikan dorongan emosional dan pemikirannya tentang perilaku seksualnya atau sikap terhadap perilaku seksualnya.

Berdasarkan hasil Survei Demografi Kesehatan Indonesia 2012 komponen Kesehatan Reproduksi Remaja (SDKI 2012 KRR), bahwa secara nasional terjadi peningkatan angka remaja yang pernah melakukan hubungan seksual pranikah dibandingkan dengan data hasil Survei Kesehatan Reproduksi Remaja Indonesia (SKRRI) 2007. Hasil survei SDKI 2012 KRR menunjukkan bahwa sekitar 9,3\% atau sekitar 3,7 juta remaja menyatakan pernah melakukan hubungan seksual pranikah, sedangkan hasil SKRRI 2007 hanya sekitar 7\% atau sekitar 3 juta remaja. Sehingga selama periode tahun 2007 sampai 2012 terjadi peningkatan kasus remaja yang pernah melakukan hubungan seksual pranikah sebanyak 2,3\%.

Pernyataan Deputi Bidang Keluarga

Berencana dan Kesehatan Reproduksi BKKBN Julianto Witjaksono yang dirilis pada tanggal 12 Agustus 2014 yang mengatakan jumlah remaja yang melakukan hubungan seks di luar nikah mengalami tren peningkatan. Berdasarkan catatan lembaganya, Julianto mengatakan 46 persen remaja indonesia berusia 15-19 tahun sudah berhubungan seks. Data Sensus Nasional bahkan menunjukkan 48-51 persen perempuan hamil adalah remaja (BKKBN,2014).

Menurut data dari Lembaga Swadaya Pemerhati Kesehatan Reproduksi Remaja (LSM-MCR) Tasikmalaya menyebutkan bahwa remaja yang banyak meminta kondom mulai usai 10-14 tahun dan 15-19 tahun. Remaja tersebut yang meminta kondom ke MCR tersebut memang menggunakannya untuk berhubungan intim. Di sisi lain kasus kehamilan pra nikah pada remaja yang meningkat dari tahun 2012 sebanyak 332 kasus dan tahun 2013 sebanyak 371 kasus. Berbagai alasan yang ditemukan menurut pengaduan remaja bahwa sebagian besar mereka mencoba-coba berperilaku seksual, alasan karena kurangnya peran orang tua, dan sering melihat film porno (Rizal, 2010).

Menurut Suryoputro dkk (2007), faktor yang berpengaruh pada perilaku seksual antara lain adalah factor personal termasukvariabel sepertipengetahuan, sikapseksualdan genderkerentanan terhadaprisiko kesehatanreproduksi,gaya hidup,harga diri, lokus control.kegiatan social,self efficacydan variable demografi(seperti: umur pubertas, jenis kelamin, statusreligiusitas, suku dan perkawinan).Faktorlingkungantermasuk variable seperti aksesdankontak dengansumber, dukungandan informasi, sosial budaya, nilai dannormasebagaidukungan sosial.

Salah satu factor yang berhubungan dengan perilaku seks pada remaja adalah pengetahuan.Pengetahuan (knowledge) adalah hasil penginderaan manusia, atau hasil tahu seseorang terhadap objek melalui indera yang dimilikinya (mata, hidung, telinga dan sebagainya) (Notoatmodjo, 2010). Pengetahuan tentang kesehatan reproduksi adalah mencakup apa yang diketahui oleh seseorang terhadap kesehatan reproduksi meliputi: sistem reproduksi, fungsi, prosesnya dan cara-cara pencegahan/penanggulangan terhadap 
kehamilan, aborsi, penyakit-penyakit kelamin (Notoatmodjo, 2007). Sedangkan Sikap adalah bentuk respons tertutup seseorang terhadap stimulus atau objek tertentu, yang sudah melibatkan faktor pendapat dan emosi yang bersangkutan seperti: senang/tidak senang, setuju/tidak setuju, baik/tidak baik (Notoatmodjo, 2007).

Tujuan dari penelitian ini adalah mengetahui gambaran pengetahuan dan sikap mahasiswa tentang perilaku seks bebas di STIKes Respati Tasikmalaya tahun 2015.

\section{METODOLOGI PENELITI}

1. Jenis penelitian

Jenis penelitian yang digunakan adalah kuantitatif dengan metode deskriptif.

2. Populasi dan sampel

Populasi dalam penelitian ini adalah seluruh mahasiswa STIKes Respati Tasikmalaya peserta pelatihan kesehatan reproduksi yaitu 72 orang. Tehnik pengambilan sampel dalam penelitian ini adalah total sampling dimana seluruh populasi dijadikan sampel dalam penelitian.

3. Waktu dan tempat penelitian

Waktu penelitian adalah bulan Agustus Oktober 2015

Tempat penelitian : Wilayah kerja Puskesmas Ciawi

4. Variabel

Variabel dalam penelitian ini adalah pengetahuan dan sikap mahasiswa tentang perilaku seks bebas.

5. Instrumen penelitian

Instrumen dalam penelitian ini menggunakan kuesioner 20 pertanyaan untuk pengetahuan dan 10 pernyataan sikap.

6. Pengolahan data

Pengolahan data penelitian dilakukan dengan cara :

\section{a. Editing}

Tahapan ini dilakukan dengan cara mengecek kelengkapan kebutuhan data penelitian.

b. Coding

Pemberian kode untuk setiap pilihan jawaban seperti :
6. Untuk variabel pengetahuan : Kode 1 untuk Baik, kode 2 untuk Cukup serta kode 3 untuk Kurang.

7. Untuk variabel sikap: Kode 1 untuk mendukung, kode 2 untuk tidak mendukung

c. Entry data

Proses memasukan data ke program komputerisasi untuk disajikan dalam bentuk tabel dan dianalisis secara narasi

d. Analisis data

Analisis data dalam penelitian ini adalah analisis univariat. Analisis ini menghasilkan distribusi frekuensi untuk menggambarkan tiap-tiap variabel yang akan diteliti.

\section{HASIL PENELITIAN}

\section{Gambaran \\ pengetahuan mahasiswa tentang perilaku seks bebas}

Berdasarkan hasil penelitian distribusi usia pelaku abortos di wilayah Puskesmas Ciawi tertera dalam tabel berikut :

Tabel 4.1

Distribusi Frekwensi Pengetahuan mahasiswa tentang perilaku seks bebas di STIKes Respati Tasikmalaya Tahun 2015

\begin{tabular}{|c|c|c|c|}
\hline No & Pengetahuan & $\mathbf{F}$ & $\%$ \\
\hline 1 & Baik & 18 & 25,0 \\
\hline 2 & Cukup & 24 & 33,3 \\
\hline 3 & Kurang & 30 & 41,7 \\
\hline & Jumlah & 72 & 100 \\
\hline
\end{tabular}

Berdasarkan tabel 4.1 didapatkan bahwa mayoritas pengetahuan mahasiswa tentang seks bebas adalah kurang yaitu 30 orang $(41,7 \%)$. 
2. Gambaran sikap mahasiswa
tentang perilaku seks bebas

Tabel 4.2

Distribusi Frekwensi sikap mahasiswa tentang perilaku seks bebas di STIKes Respati Tasikmalaya Tahun 2015

\begin{tabular}{|c|l|c|c|}
\hline No & \multicolumn{1}{|c|}{ Sikap } & F & \% \\
\hline 1 & Mendukung & 9 & 12,5 \\
\hline 2 & Tidak mendukung & 63 & 87,5 \\
\hline & Jumlah & $\mathbf{7 2}$ & $\mathbf{1 0 0}$ \\
\hline
\end{tabular}

Berdasarkan tabel 4.2 didapatkan bahwa mayoritas sikap mahasiswa tentang perilaku seks bebas adalah tidak mendukung yaitu $87,5 \%$.

\section{E. PEMBAHASAN}

1. Pengetahuan tentang perilaku seks bebas

Berdasarkan hasil penelitian diperoleh data bahwa pengetahuan remaja tentang seks sebas sebagan besar termasuk kurang $(41,7 \%)$, berpengetahuan cukup $(33,3 \%)$ dan berpengetahuan baik $(25,0 \%)$. Hal tersebut dapat diasumsikan bahwa dalam pengetahuantentang seks bebas belum mendapat informasi yang baik, sehingga dengan kondisi tersebut akan menimbulkan sebuah perilaku atau masalah yang akan cenderung melakukan seks bebas karena ketidak tahuan remaja mengenai permasalahan dan dampakyang ditimbulkan atau bisa dikatakan akan berpotensi untuk berperilaku mencobacoba seperti berpegangan tangan,berciuman dan melakukan seks bebas.

Hasil kuesioner menunjukan pertanyaan yang paling banyak di jawab benar oleh sebagian besar responden adalah nomor 1 tentang definisi seksual secara umum yaitu 63 orang (88\%), selanjutnya soal yang paling sedikit dijawab benar yaitu 14 tentang akibat melakukan hubungan seksual di luar nikah sebanyak 23 orang (32\%).
Salah satu factor yang berhubungan dengan perilaku seks pada remaja adalah pengetahuan.Pengetahuan (knowledge) adalah hasil penginderaan manusia, atau hasil tahu seseorang terhadap objek melalui indera yang dimilikinya (mata, hidung, telinga dan sebagainya) (Notoatmodjo, 2010). Pengetahuan tentang kesehatan reproduksi adalah mencakup apa yang diketahui oleh seseorang terhadap kesehatan reproduksi meliputi: sistem reproduksi, fungsi, prosesnya dan cara-cara pencegahan/penanggulangan terhadap kehamilan, aborsi, penyakit-penyakit kelamin (Notoatmodjo, 2007).

Pengetahuan seks pranikah remaja dapat mempengaruhi sikap individu terhadap seksual pranikah.Karena pengetahuan merupakan salah satu faktor penting dalam pembentukan sikap seorang remaja yang memasuki masa meralihan.Pengetahuan juga dapat merubah persepsi seseorang tentang seksualitas tersebut (Adikusumo, 2005).

Hasil penelitian ini sesuai dengan penelitian yang dilakukan oleh Yolanda pada tahun 2012 di Menado, mayoritas pengetahuan mahasiswa tentang perilaku seks bebas termasuk kategori kurang.

Asumsi peneliti dibutuhkan upaya yang dalam peningkatan pengetahuan mahasiswa tentang resiko perilaku seks bebas memelalui penyuluhan, konseling serta peer group teman sebaya.

\section{Sikap dan perilaku seks bebas}

Hasil penelitian yang diperoleh secara langsung dari responden melalui kuesioner dengan hasil sebagian besar tidak mendukung terhadap perilaku seks bebas $(87,5 \%)$ dan yang mendukung $(12,5 \%)$. Data tersebut menunjukkan bahwa sebagian besar responden mempunyai sikap atau beranggapan seksual bebas merupakan hal yang harus dihindari baik dalam bentuk eksplorasi, masturbasi maupun perilaku lainnya. 
Hasil penelitian dilapangan menunjukkan bahwa sebagian besar responden tidak setuju adanya perilaku seksual bebas, responden tidak setuju bahwa membacara buku dan majalah porno tidak wajar dilakukan remaja, tidak wajar remaja berdiskusi tentang seksualitas dengan pasangannya, ciuman pipi dengan pipi, bibir dengan pipi, adalah suatu prilaku yang tidak normal untuk menunjukan rasa sayang pada pasangannya.

Akan tetapi terdapat responden yang bersifat mendukung terhadap seks bebas. Mereka beranggapan perilaku seksual merupakan perilaku yang didasari oleh dorongan seksual atau kegiatan mendapatkan kesenangan organ seksual melalui berbagai perilaku, misalnya fantasi, masturbasi, berpegangan tangan, cium pipi, berpelukan, cium bibir, petting dan berhubungan intim.

Sikap adalah bentuk respons tertutup seseorang terhadap stimulus atau objek tertentu, yang sudah melibatkan faktor pendapat dan emosi yang bersangkutan seperti: senang/tidak senang, setuju/tidak setuju, baik/tidak baik (Notoatmodjo, 2007).

Sikap seksual adalah respon seksual yang diberikan seseorang setelah melihat, mendengar atau membaca informasi serta pemberitaan, gambar-gambar yang berbau porno dalam wujud orientasi atau kecenderungan dalam bertindak.Sikap yang dimaksud adalah sikap remaja terhadap perilaku seksual (Bungin, 2001).Pengukuran sikap dapat dilakukan secara langsung maupun tidak langsung.Secara langsung dapat dinyatakan bagaimana pendapat atau pernyataan responden terhadap suatu objek secara tidak langsung dapat dilakukan dengan pernyataan hipotesis-hipotesis kemudian dinyatakan pendapat responden melalui kuesioner (Notoatmodjo, 2003).

Asumsi peneliti untuk responden yang memiliki sikap mendukung terhadap perilaku seks bebas dibutuhkan penanaman pemahaman yang baik tentang resiko perilaku seks bebas sehingga terbentu persepsi yang kuat yang turut membentuk sikap tidak mendukung terhadap perilaku seks bebas.

\section{F. SIMPULAN DAN SARAN}

1. Simpulan

a. Mayoritas pengetahuan mahasiswa tentang seks bebas adalah kurang yaitu 30 orang $(41,7 \%)$.

b. Mayoritas sikap mahasiswa tentang perilaku seks bebas adalah tidak mendukung yaitu $87,5 \%$.

2. Saran

a. Mahasiswa

Diharapkan mahasiswa dapat meningkatkan pencarian informasi tentang resiko perilaku seks bebas pada remaja melalui penyuluhan dan konseling.

b. Petugas kesehatan

Dapat dijadikan bahan acuan dalam penyusunan perencanaan kegiatan kesehatan reproduksi pada remaja melalui penyuluhan dan konseling secara berkesinambungan.

\section{G. DAFTAR PUSTAKA}

Ambarwati. 2009. Asuhan Kebidanan Komunitas. Nuha Medika. Jogjakarta.

Indrawati, 2010. Panduan Perawatan Kehamilan. Jogjakarta. Atma Media Press

Notoatmodjo. 2007. Kesehatan

Masyarakat: Teori dan Aplikasi. Rineka Cipta. Jakarta

Notoatmodjo. 2010. Promosi kesehatan: Teori dan Aplikasi. Rineka Cipta. Jakarta

Nottoatmodjo. 2010. Metodologi kesehatan. Rineka Cipta. Jakarta

Nuha Medika. Jogjakarta.Notoatmodjo. 2005. Promosi Kesehatan: ilmu dan Seni. Rhineka Cipta. Jakarta

Rizal, 2010. MCR Tasikmalaya

Sarwono. 2007. Ilmu Kebidanan. Bina Pustaka. Jakarta

Survei Data Kesehatan Indonesia tahun 2012

Wawan dan Dewi, 2010. Pengukuran Pengetahuan, Sikap dan Perilaku Manusia. 
Yolanda,. 2012. Hubungan antara pengetahuan dan sikap mahasiswa tentang perilaku sek 